University of New Hampshire

University of New Hampshire Scholars' Repository

10-27-2002

\title{
Determination of subpixel fractions of nonforested area in the Amazon using multiresolution satellite sensor data
}

\author{
Stephen Hagen \\ University of New Hampshire - Main Campus \\ Rob Braswell \\ University of New Hampshire - Main Campus, rob.braswell@unh.edu \\ Steve Frolking \\ University of New Hampshire - Main Campus, steve.frolking@unh.edu \\ William A. Salas \\ University of New Hampshire - Main Campus \\ Xiangming Xiao \\ University of New Hampshire - Main Campus
}

Follow this and additional works at: https://scholars.unh.edu/earthsci_facpub

\section{Recommended Citation}

Hagen, S. C., B. H. Braswell, S. Frolking, W. A. Salas, and X. Xiao, Determination of subpixel fractions of nonforested area in the Amazon using multiresolution satellite sensor data, J. Geophys. Res., 107 (D20), 8049, doi: ref="info:doi/doi:10.1029/2000JD000255">doi:10.1029/2000JD000255, 2002.

This Article is brought to you for free and open access by the Earth Sciences at University of New Hampshire Scholars' Repository. It has been accepted for inclusion in Earth Sciences Scholarship by an authorized administrator of University of New Hampshire Scholars' Repository. For more information, please contact Scholarly.Communication@unh.edu. 


\title{
Determination of subpixel fractions of nonforested area in the Amazon using multiresolution satellite sensor data
}

\author{
S.C. Hagen, B.H Braswell, ${ }^{1}$ S. Frolking, W.A. Salas, and X. Xiao \\ Complex Systems Research Center, University of New Hampshire, Durham, New Hampshire, USA
}

Received 11 December 2000; revised 11 June 2001; accepted 12 June 2001; published 4 September 2002.

[1] We present the results of an analysis that combines coarse and fine spatial resolution remote sensing data to reconstruct time series of nonforested area in a region of the Brazilian Amazon. We used a 10-year sequence (1989-1998) of Landsat Thematic Mapper data for one scene $\left(\sim 30,000 \mathrm{~km}^{2}\right)$ in Rondônia, Brazil, to parameterize a regression model that uses subsets of AVHRR GAC reflectance data. This model detected information on interannual changes in nonforested area with a combination of detail and coverage greater than would normally be available using either data set alone. Within this domain we retrieved nonforest cover fraction in a cross-validation test with coefficients of determination $\left(R^{2}\right)$ of 0.32 at $8-\mathrm{km}$ resolution and 0.64 at $48-\mathrm{km}$ resolution. At the $48-\mathrm{km}$ resolution the model captures interannual variability and trends of fractional cover within individual pixels that changed considerably over the 10 years of this analysis. The results for this region suggest that retrospective analyses will benefit from further development of techniques combining AVHRR, TM, and other prior information. INDEX TERMS: 1615 Global Change: Biogeochemical processes (4805); 1640 Global Change: Remote sensing KEYWORDS: Amazonia, land cover, deforestation, Landsat, AVHRR, remote sensing

Citation: Hagen, S. C., B. H. Braswell, S. Frolking, W. A. Salas, and X. Xiao, Determination of subpixel fractions of nonforested area in the Amazon using multiresolution satellite sensor data, J. Geophys. Res., 107(D20), 8049, doi:10.1029/2000JD000255, 2002.

\section{Introduction}

[2] The direct alteration of terrestrial ecosystems by humans has played a significant role in the changing global carbon cycle [Schimel, 1995; Houghton et al., 2000]. Principal driving forces behind these land cover changes, such as population dynamics and institutional economic and political factors, have been identified [Allen and Barnes, 1985; Hecht and Cockburn, 1989; Turner, et al., 1994; Skole et al., 1994] and some integrative models exist [e.g., Frohn et al., 1996; Pfaff, 1999]. However, prediction of large-scale socioeconomic systems is difficult and current land cover change research relies principally on monitoring via inventory and satellite imagery.

[3] In tropical South America, political and economic pressures have combined to create sustained but variable impacts on the land cover [Fearnside, 1990; Houghton, 1991]. The dynamics of land cover change in this region can be described by a simple conceptual model with three (or more) possible land cover states and the corresponding sequence of transitions between them [Fearnside, 1996]. A fraction of primary forest in a given region of interest can be cleared for pasture or cultivation. The cleared areas can then be maintained as agricultural land or abandoned. Secondary forests may also be subject to cyclical land-use patterns and are often returned to pasture or agriculture before reaching maturity [Fearnside, 1996; Salas, 2001]. The resulting patches of forest regrowth on abandoned land (secondary forests) form a mosaic of vegetation types and structure. This situation is further complicated in some regions

\footnotetext{
${ }^{1}$ Also at Max Planck Institute for Biogeochemistry, Jena, Germany. Copyright 2002 by the American Geophysical Union.
} 0148-0227/02/2000JD000255 by partial clearing associated with logging, which is difficult to assess completely with any existing monitoring method but is believed to be significant [Nepstad et al., 1999].

[4] Satellite remote sensing has been used to document the transitions between tropical forest, agricultural land, and secondary forest [Skole and Tucker, 1993; Chomentowski et al., 1994; Stone et al., 1991]. Many of these analyses are limited by uncertainties in the observations and the intrinsic trade-off between spatial and temporal resolution of the data.

[5] A significant amount of research has focused on using coarse resolution remote sensing data, such as the advanced very high resolution radiometer (AVHRR), for mapping deforestation because of its broad spatial coverage, frequent overpass time, and low cost. These studies classify whole pixels (at a minimum resolution of $1.1 \mathrm{~km}$ ) as a single land cover class. For example, Tucker et al. [1985] used AVHRR local area coverage (LAC) data to map land cover in Africa, and Woodwell et al. [1987] mapped deforestation in the Amazon Basin with AVHRR LAC data. Also, Nelson and Holben [1986] examined the utility of coarser spatial resolution AVHRR global area coverage (GAC) data for identifying clearings in Rondônia and determined that while the high temporal resolution of the instrument (almost daily) is desirable, the clearings were too small to be resolved at the 4-km AVHRR GAC resolution. From these studies we see that coarse to moderate resolution remote sensing alone cannot resolve many of the important details of land cover dynamics in tropical forests because these details occur at scales smaller than the resolution of the instrument. On the other hand, it is desirable to exploit the high temporal frequency and broad spatial coverage of global (coarse resolution) remote sensing data sets. High temporal frequency is advantageous, not because land cover is 
likely to change significantly in the nominal 16-day gap between Landsat images, but because an instrument that gathers images daily is much more likely to capture cloud-free glimpses of regional land cover on a consistent basis. This is particularly true in the humid tropics, where cloud cover is persistent [Asner, 2001].

[6] Many studies have used fine spatial resolution data (e.g., Landsat (MSS) and (TM)) to classify land cover in the tropics for localized areas the size of a TM scene or smaller [e.g., Li et al., 1994; Steininger, 2000]. Additionally, times series of land cover change have been assembled for similarly small regions in the Amazon using multiple acquisitions of fine resolution data [Mausel et al., 1993; Lucas et al., 1993; Alves and Skole, 1996; Kimes et al., 1999]. Nelson et al. [2000] constructed a 7-year annual time series for a single TM scene in Rondônia with no temporal gaps (longer than 1 year) in a study of secondary forest age. Skole and Tucker [1993] completed a broader spatial analysis by assembling a land cover classification for the entire Amazon Basin for 1978 and 1988 using Landsat imagery. The studies that use fine resolution remote sensing exclusively have been limited either in their spatial coverage, usually to a single Landsat TM scene, or in their temporal resolution (i.e., they contain gaps longer than 1 year). Covering the Brazilian Legal Amazon requires over 200 Landsat scenes. Given this high data volume, in combination with the persistence of clouds in the tropics and low overpass frequency (16 days) of Landsat, mapping large regions like the Amazon Basin on an annual basis with Landsat imagery alone is prohibitive [Tucker and Townshend, 2000].

[7] Woodwell et al. [1987] suggested that a more efficient and economical approach than using AVHRR or Landsat data alone would be to integrate the two products by using calibration factors that take advantage of both the finer resolution of Landsat and the more complete spatial and temporal coverage of AVHRR. Many studies have combined fine and coarse spatial resolution data for multiresolution analysis [e.g., $\mathrm{Nel}$ son, 1989; Holben and Shimabukuro, 1993; Foody and Cox, 1994; Puyou-Lascassies et al., 1994; Oleson et al., 1995; Kerdiles and Grondona, 1995; Mayaux and Lambin, 1995; Atkinson et al., 1997; Asner et al., 1997]. For example, Foody et al. [1997] used Landsat TM data and an artificial neural network to unmix fractional land cover within AVHRR pixels. Iverson [1989, 1994] used Landsat TM data to create a regression model to estimate the fraction of forest cover within an AVHRR pixel instead of classifying whole AVHRR pixels as a single land cover. Others [e.g., Zhu and Evans, 1994; Ripple, 1994; Hlavka and Spanner, 1995] have used Iverson's approach for regional assessments of land cover in a variety of locations. In this paper we extend this approach from single-year calibrated unmixing analysis to a time series of annual land cover assessments. We explore the potential of using multiresolution remote sensing data in a generalizable way to monitor yearto-year changes in nonforested area of tropical regions at coarse spatial scales appropriate for use with climate and terrestrial models.

\section{Site Description and Methods}

[8] This study focuses on $\sim 30,000 \mathrm{~km}^{2}$ of land surrounding the city of Ariquemes in Rondônia, Brazil (Figure 1). Several other tropical land cover change studies focused on this area [e.g., Stone et al., 1991; Alves et al., 1999; Nelson et al., 2000]. The native vegetation in the area is predominantly dense trop- ical forest, with smaller areas of savanna, grassland, and alluvial vegetation [Alves and Skole, 1996]. Rondônia has been the site of some of the fastest rates of land clearing and population growth in the tropical world. Before 1960 the area was sparsely populated, but since the early 1970s, Rondônia has experienced a tremendous rate of immigration and land use change [Stone et al., 1991].

[9] We used two spatially and temporally coincident data sets for this study: a fine resolution time series of land cover for one TM scene and AVHRR GAC reflectance observations for the same area. Data preprocessing included degrading the fine resolution land cover data to fractional cover at an $8-\mathrm{km}$ resolution, which results in a single data layer for each class. Then, using the geolocation information provided with the data and ground control points identifiable in both data sets (e.g., large clearings associated with highways and cities), we coregistered the data sets with image visualizing software. Because alignment of the data features is difficult at the $8-\mathrm{km}$ scale, we evaluated the coregistration by shifting the data one $8-\mathrm{km}$ pixel at a time in each direction and noting the correlation between reflectance (AVHRR) and land cover fraction (TM). The test indicated no significant improvement in coregistration would result from a whole-pixel shift, so we conclude that the coregistration is accurate to within one $8-\mathrm{km}$ pixel.

[10] The land cover data were derived from a sequence of 30-m resolution Landsat TM images [Salas, 2001]. The data set consists of 10 classified scenes, one per year from 1989 to 1998, for the same area around the city of Ariquemes in Rondônia, Brazil [Nelson et al., 2000; Salas, 2001]. Each 30-m pixel is classified as either mature forest, cleared area, secondary forest, cerrado, water, or cloud (see Nelson et al. [2000] for details of the classification procedure). The resulting product is a time series of land cover for each 30-m pixel in the scene. The total area cleared for pasture and agriculture within the region of this TM scene roughly doubled between 1989 and 1998, while the majority of the scene remained forested (Figures 2 and 3).

[11] Ten years (1989-1998) of AVHRR GAC data (10-day maximum NDVI value composite at $8-\mathrm{km}$ resolution) were acquired from the NASA Pathfinder AVHRR land (PAL) reprocessing effort [James and Kalluri, 1994]. In this study we used Channel 1 (red, 0.58-0.68 $\mu \mathrm{m}$ ), Channel 2 (near infrared, 0.725-1.1 $\mu \mathrm{m}$ ), and Channel 3 (mid-infrared to thermal, 3.55$3.93 \mu \mathrm{m}$ ) data. We used Channels 1 and 2 reflectance values to calculate the normalized difference vegetation index (NDVI $=$ $[(\mathrm{Ch} 2-\mathrm{Ch} 1) /(\mathrm{Ch} 2+\mathrm{Ch} 1)])$. This index has been shown both in theory and in observations to be related to the amount of photosynthetic material in a canopy volume [Myneni et al., 1995; Asrar et al., 1984]. Therefore we assumed it is a good indicator of the amount of forest and nonforest area within a pixel because of their highly contrasting foliage density. We used Channel 3 data because it has also been shown to be sensitive to this contrast [Malingreau et al., 1996].

[12] To further reduce the effects of the atmosphere (e.g., spatial and temporal variations in water column vapor, clouds, aerosols) which tend to decrease the measured NDVI, we recomposited the AVHRR data to generate monthly data by extending the NDVI maximum-value compositing [Holben 1986; Asner et al., 2000]. We selected the Channel 3 value from the 10-day composite associated with the maximum-value NDVI. These monthly values were subsequently averaged over the dry season (May to September) of each year (1989-1998). This resulted in annual NDVI and Channel 3 time series at 8 


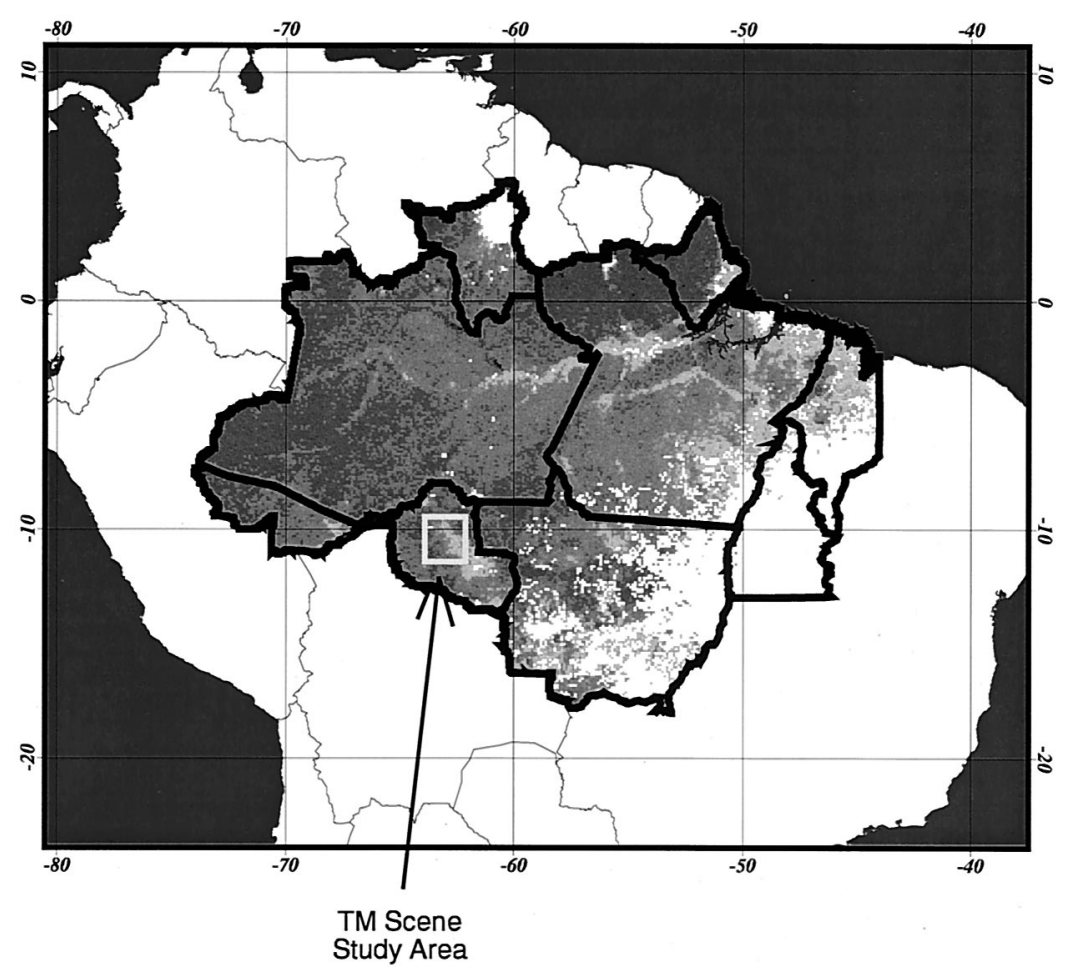

Figure 1. Region of study (rectangle) is located in Rondônia, Brazil, in the southwestern portion of the Legal Amazon (composed of the states in the dark outline). The color of $8-\mathrm{km}$ pixels in the Legal Amazon represents the magnitude of the first principal component of Channels 1, 2, and 3 in the 13-year-averaged AVHRR data. This view, which combines all the available AVHRR reflectance data for each pixel, reveals details of land cover such as the cleared area in Rondônia and along the Trans-Amazon Highway (orangepink-red coloring) and suggests usefulness of AVHRR time series data in identifying nonforested areas. See color version of this figure at back of this issue.

$\mathrm{km}$ for the area defined by the TM time series (smaller grid overlay in Figure 2).

[13] We created a second, coarser resolution product for this analysis by aggregating the $8 \mathrm{~km}$ AVHRR data to $48 \mathrm{~km}$. Our reasons for this were threefold. First, each 8-km AVHRR GAC pixel is composed of an irregular subsampling of $1.1 \mathrm{~km}$ LAC pixels, not an average of all of the $1.1 \mathrm{~km}$ pixels. Aggregating to $48 \mathrm{~km}$ probably produces a more representative average of the reflectance from the land cover, due to the larger sample size. Second, aggregating to $48 \mathrm{~km}$ reduces the effects of sub-8-km coregistration errors which would be apparent at the $8-\mathrm{km}$ scale. Finally, at a $48-\mathrm{km}$ resolution, pixels are commensurate with the spatial resolution of regional to global scale biogeochemical models $\left(0.5^{\circ}\right.$ latitude/longitude near the equator) [e.g., Tian et al., 1998].

[14] Using the spatially coregistered AVHRR and TM data, we determined the fractional cover of land cover types at the 8 - and 48-km scales based on the classified 30-m TM data. We combined the classes of cleared area and cerrado into a single nonforest class because these classes are spectrally indistinguishable at all AVHRR wavelengths. Secondary forest was defined in the Landsat classification as those areas abandoned and supporting forest after the original vegetation has been cleared [Nelson et al., 2000]. Spectrally, regenerating forests exhibit reflectances somewhere between cleared land and mature forest, depending on the structure of the forest, which varies with age and regeneration stage [Uhl et al., 1988; Brown and Lugo, 1990].

[15] After temporal recompositing and spatial aggregation, substantial interannual variability was apparent in the AVHRR data (Figure 4) in excess of variability that could reasonably be attributed to changes in vegetation cover alone. This spurious variability, linked to year-to-year clustering, is most likely due to changes in column water vapor, satellite drift, and aerosol optical depth, although sensor degradation and geolocation issues are also likely to play some role [Asner et al., 2000]. We reasoned that a change in the relative location of a pixel within its annual cluster in NDVI/Channel 3 space was related to a change in the nonforest fraction in that cell, while year-to-year changes in the location of the clusters were due to nonvegetation effects. Therefore to minimize this interannual noise and to preserve the relative location of a pixel within its annual cluster, we standardized the data by subtracting the mean values for "reference" pixels that remained dominated by forest ( $>95 \%$ mature forest, $\sim 1 / 5$ of all 8 -km pixels) over the 10 -year time series and dividing this difference by the standard deviation of the reference pixels. We assumed there is no interannual variability in undisturbed forest pixels, averaged over the dry season. Some climate-driven effects related to moisture constraints on phenology may exist [Batista et al., 1997; Asner et al., 2000], but we assume that this variability would not be large enough to interfere with the discrimination between forest and nonforest. The standardization necessarily eliminated interannual drift (Figure 4 and 5) and allowed us to focus on changes in nonforested area. After aggregating the original PAL 8-km AVHRR data to $48 \mathrm{~km}$, we performed the same standardization procedure with the $48-\mathrm{km}$ values, requir- 


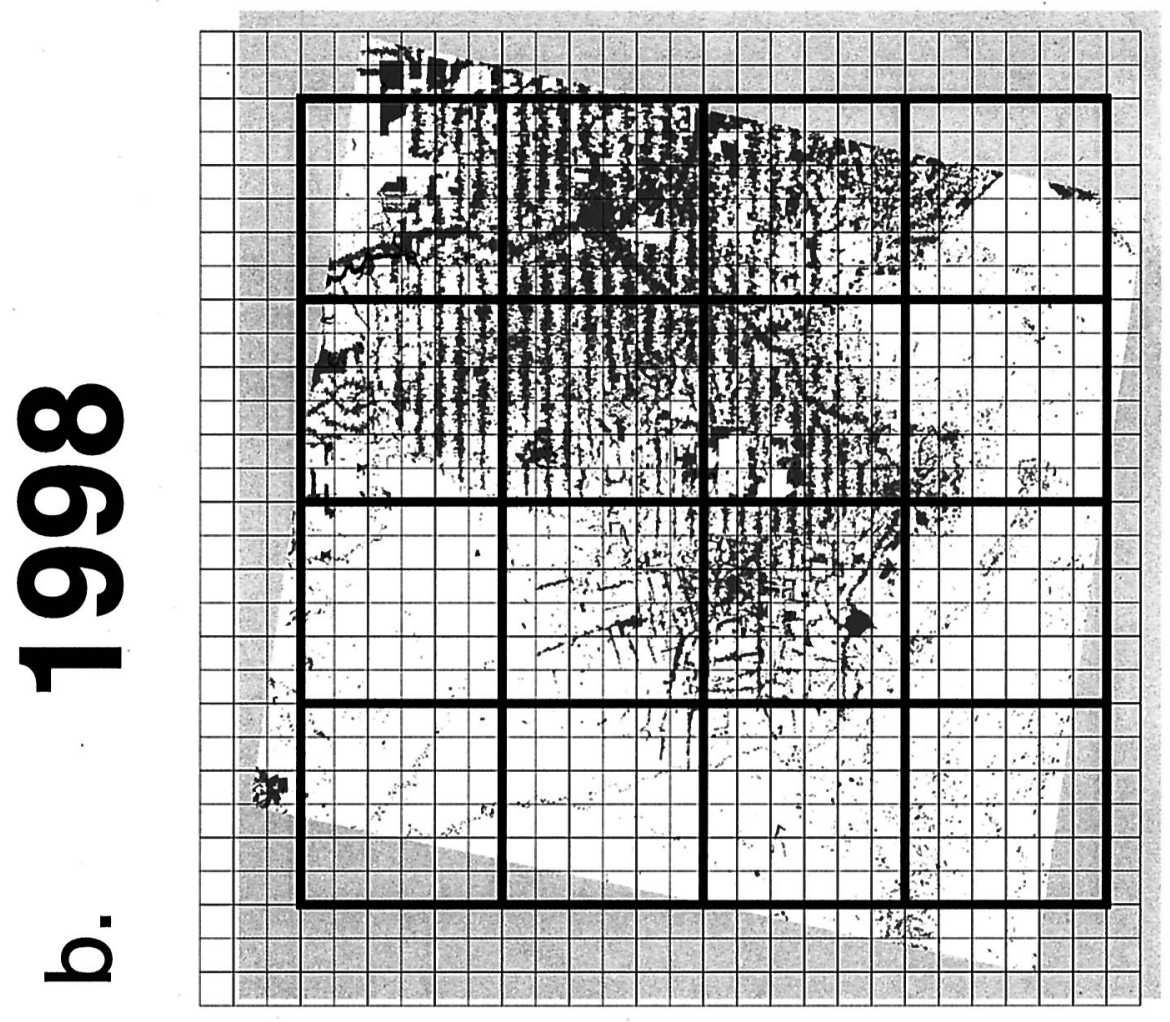

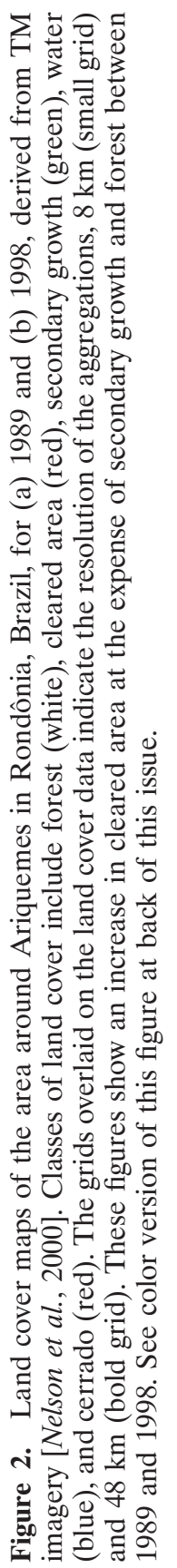
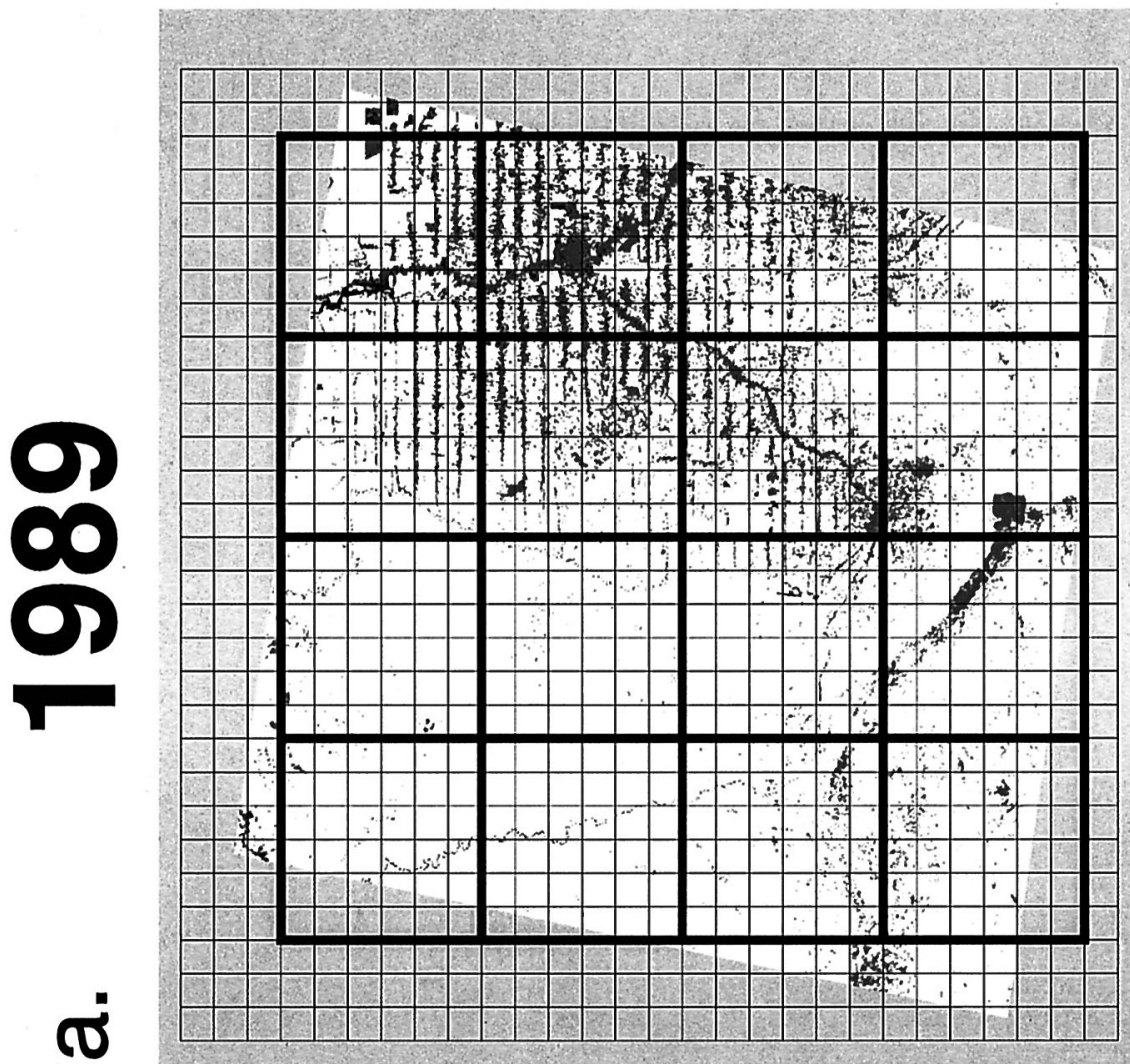


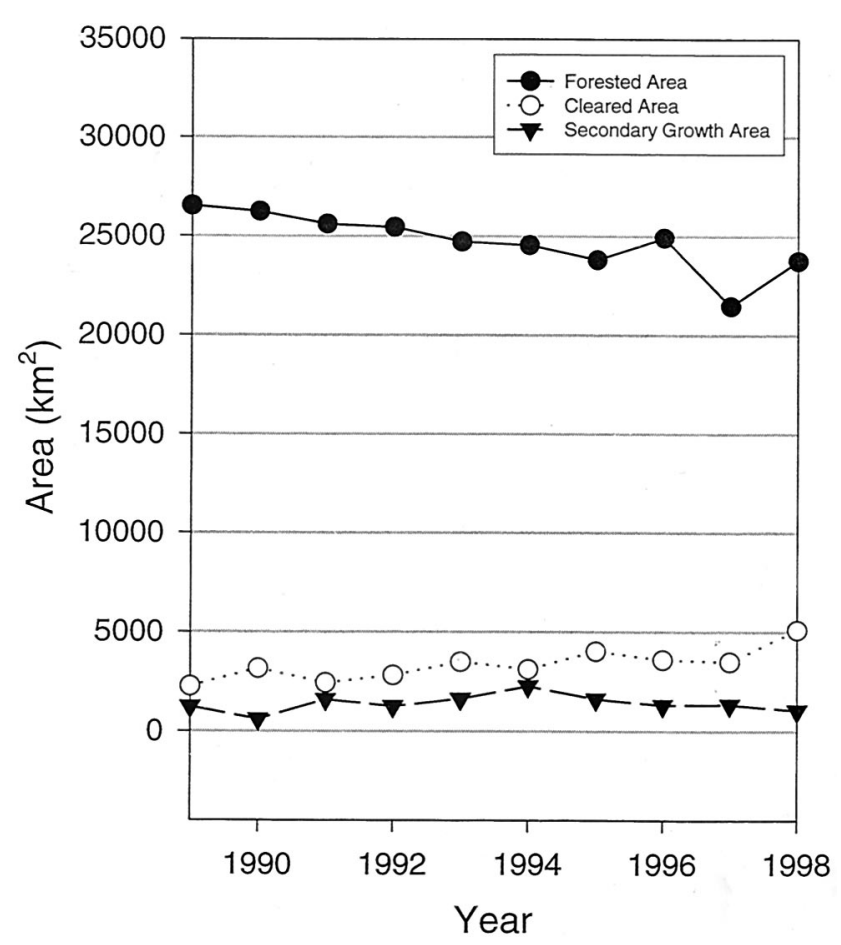

Figure 3. Land cover dynamics between 1989 and 1998 over the area covered by TM-derived land cover maps, showing a decrease in forested area over time. The sharp decline (1996$1997)$ then increase (1997-1998) in forested area is mostly due to significant cloud cover $(\sim 15 \%)$ in the $1997 \mathrm{TM}$ scene rather than deforestation and near-instantaneous regrowth. The scene remains mostly forested throughout the time series.

ing that reference pixels always contain at least $90 \%$ mature forest (about $1 / 5$ of the $48-\mathrm{km}$ pixels).

[16] Data from two of the original 10 years were excluded from the analysis: 1995, because the AVHRR observations were incomplete due to satellite malfunction; and 1997, because of an excessive amount of cloud cover $(\sim 15 \%)$ in the classified TM scene [Nelson et al., 2000]. With these years removed, the $8-\mathrm{km}$ standardized data from the remaining 8 years consisted of 3760 data points ( 470 grid cells $\times 8$ years, Figure 5a). The 48-km data set consisted of 120 data points (15 pixels $\times 8$ years, Figure $5 \mathrm{~b})$. The grid cell in the southeast corner was left out of this analysis because most of its area falls out of the TM scene most years (Figure 2).

[17] We analyzed the sets of "data pairs" (i.e., the standardized values from AVHRR and the nonforested area from TM for each pixel) by fitting a linear model for the amount of nonforested area $\left(A_{\mathrm{nf}}\right)$ within a pixel as a function of the AVHRR data:

$$
A^{\prime}{ }_{\mathrm{nf}}=\beta_{0}+\beta_{1}(\mathrm{NDVI})+\beta_{2}\left(\text { Channel 3) }=A_{\mathrm{nf}}+\varepsilon,\right.
$$

where the coefficients $\beta_{0}, \beta_{1}$, and $\beta_{2}$ are estimated by regression, and $\varepsilon$ is the residual error.

[18] Estimates of nonforested area were then produced and examined at both the 8 - and the $48-\mathrm{km}$ resolution. The regression model in equation (1) was fit using all the years of data grouped together, generating one set of coefficients $(\beta)$. Additionally, lacking independent data for validation of the model, we performed a cross validation. The cross validation involved fitting a model iteratively using all the data points except one year's data, which was set aside for testing. The cross-validation process generated eight sets of coefficients, one for each year.

[19] As an exploration into the spectral characteristics of secondary forest, we added a free parameter, $f$, where $0 \leq f \leq$ 1 , indicating the fraction of secondary forest included in the nonforest class. Adjusting this fraction between zero (i.e., include all secondary forest in the forest class) and one (i.e., include all secondary forest in the nonforest class) could provide information about the signature of secondary forest (i.e., its similarity to nonforest and forest). The effective nonforest area $\left(A_{\mathrm{nf}}\right)$ is given by

$$
A_{\mathrm{nf}}=A_{\text {cleared }}+A_{\text {cerredo }}+f\left(A_{\mathrm{sf}}\right),
$$

where $A_{\text {cleared }}$ is the area classified as cleared (according to the 30-m classification), $A_{\text {cerrado }}$ is the area classified as cerrado, and $A_{\text {sf }}$ is the area classified as secondary forest. We began our analysis by assuming that secondary forest does not contribute to the nonforest signal $(f=0)$ and examined the effects of this assumption later in our analysis. Finally, we considered in a stepwise fashion the necessity of using both NDVI and Channel 3 terms in equation (1) and the relative value of using NDVI versus the red and near-infrared reflectances in the regression.

\section{Results and Discussion}

[20] After standardization the mean location of forestdominated pixels (arbitrarily defined as $<25 \%$ nonforest with $f=0)$ and nonforested pixels ( $\geq 25 \%$ nonforest with $f=0)$ in Channel-3-NDVI phase space were significantly different $(p<$ 0.05 ) in both the $8-\mathrm{km}$ and the $48-\mathrm{km}$ analysis (Figure 2 ). This result indicates that standardization reduced the effects of many nonvegetation-related artifacts and that the AVHRR data contain information that will help resolve the amount of nonforested area within a pixel.

[21] We included both NDVI and Channel 3 in the regression model, in part, because both variables, individually, are more significantly correlated with nonforested area (at the 48km scale, Pearson correlation coefficient $R=0.84$ and -0.57 , respectively) than with each other $(R=-0.46)$, suggesting that they may contain independent information. Additionally, several studies have suggested that both NDVI and Channel 3 are related to the disturbed area, though it is not clear whether they contain independent information [Woodwell, 1987; Malingreau et al., 1996; Di Maio Mantovani and Setzer, 1997]. The analysis of variance for the regression model also indicated that both Channel 3 and NDVI significantly captured variation in nonforested areas. The results from these preliminary investigations are not strongly suggestive of independence between Channel 3 and NDVI, so it remains unclear whether Channel 3 is needed for unmixing fractions of nonforested area within large grid cells. We proceeded conservatively by employing a model containing both variables.

[22] The relationship between AVHRR NDVI and TM nonforested area was stronger at the $48-\mathrm{km}$ resolution than at the $8-\mathrm{km}$ resolution $(R=0.84$ versus 0.56$)$. The same results are seen in the relationship between Channel 3 and TM nonforested area for the two resolutions $(R=-0.57$ versus $-0.37)$. The results from the regression model, of the form given in equation (1), which combines NDVI and Channel 3, 


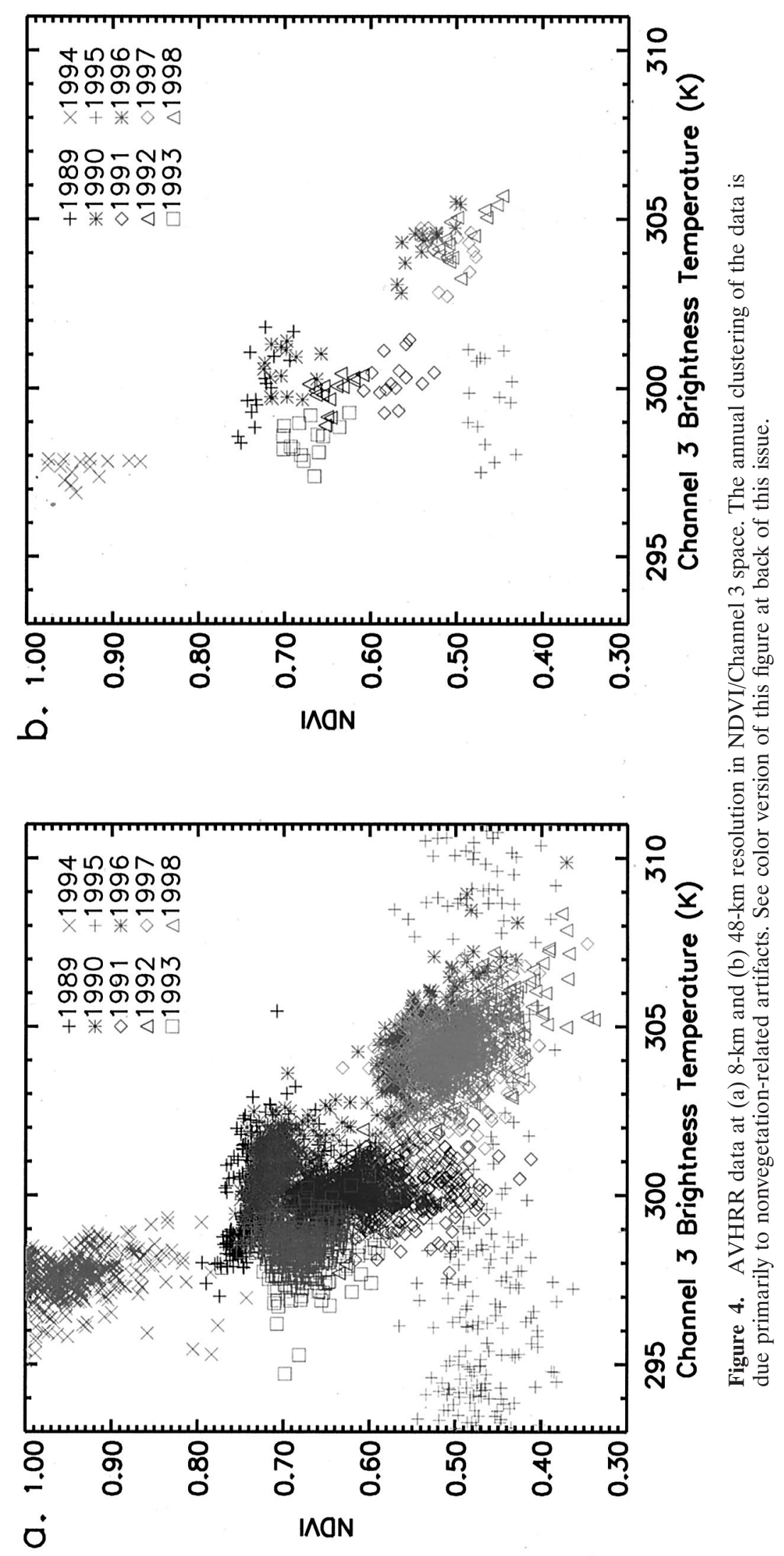



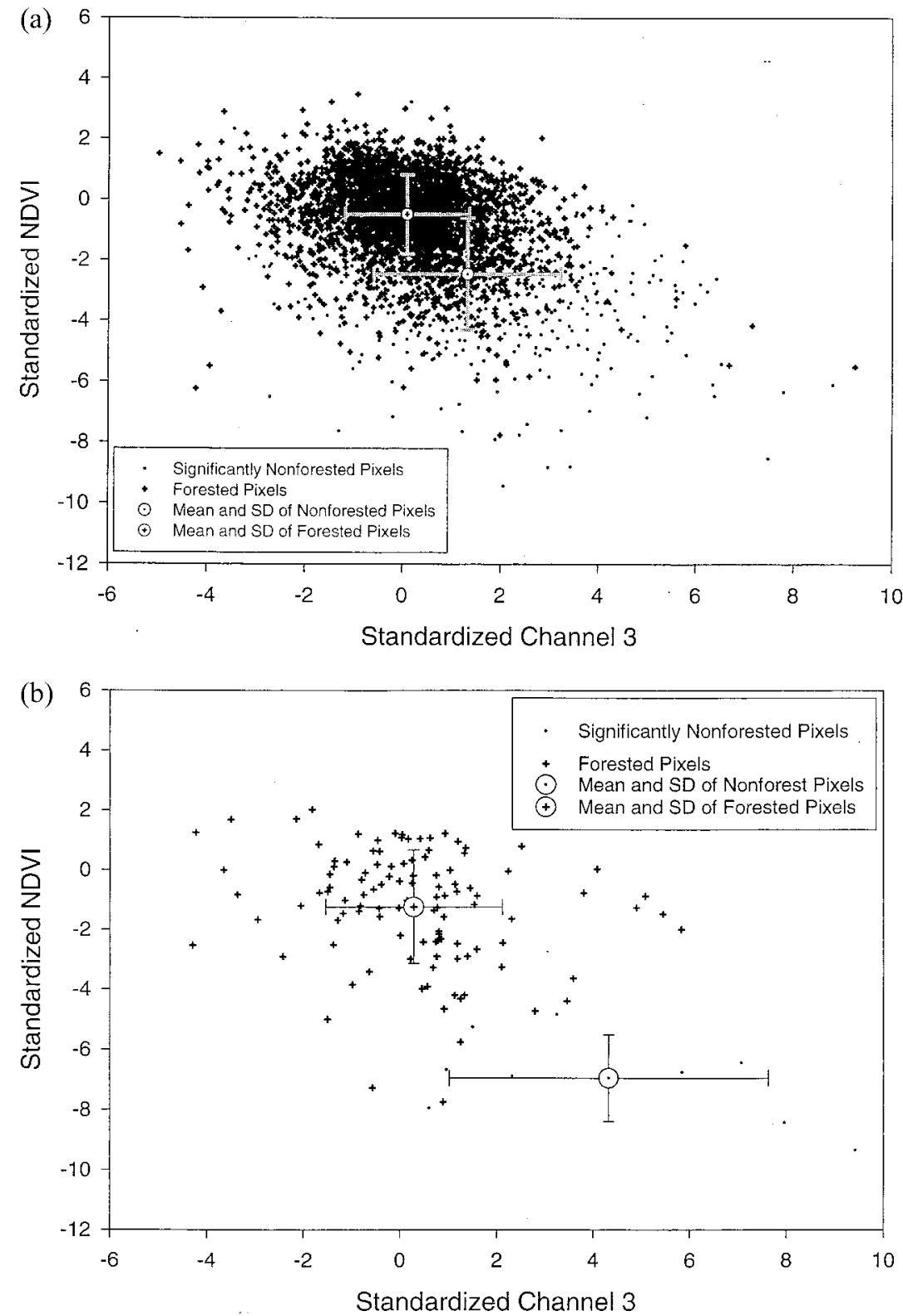

Figure 5. AVHRR standardized data at (a) $8-\mathrm{km}$ and (b) $48-\mathrm{km}$ resolution in NDVI/Channel 3 space. The annual clusters evident in nonstandardized data (Figure 4) are not identifiable here. The data are split into two groups using the TM land cover data. Forested pixels (pluses) are those with more than 75\% forested area. Significantly nonforested pixels (dots) are those with at least $25 \%$ nonforested area. The figure also shows the means and standard deviations of the groups of pixels along the NDVI and Channel 3 axis.

reveal the same improvement of the $48-\mathrm{km}$ resolution data over the $8-\mathrm{km}$ data. The coefficient of determination $\left(R^{2}\right)$ was 0.75 for the $48-\mathrm{km}$ regression model and 0.35 for the $8-\mathrm{km}$ model. The residual errors, $\varepsilon$, for the $48-\mathrm{km}$ model were approximately normally distributed, while the $8-\mathrm{km}$ model showed heteroscedasticity (visual inspection).

[23] An analysis of how to account for secondary forest class gave no decisive answers. At both the $8-\mathrm{km}$ and the $48-\mathrm{km}$ resolution, the coefficient of determination $\left(R^{2}\right)$ of the model was relatively insensitive to the fraction of secondary forest included in the nonforest class (Figure 6). To simplify the analysis, $f$ was fixed at a single value $(f=0)$, thereby including all of the regenerating forest in the forest class and none in the nonforest class. We examined other potential models by including
AVHRR Channels 1 and 2 in place of NDVI. Studies have shown that near-infrared reflectance (Channel 2) is strongly related to the tropical forest regeneration stage [e.g., Lucas et al., 2000]. In this study, these alternative models showed no improvement and were similarly unaffected by a change in $f$.

[24] The results of the iterative cross-validation procedure also depended upon the scale considered (Figure 7). At the 8 -km scale the $R^{2}$ was 0.32 and the root-mean-square error (RMSE) was $7.1 \mathrm{~km}^{2}$ (11\% of the grid cell area). At the $48-\mathrm{km}$ scale the model produced an $R^{2}$ value of 0.64 and a RMSE of $146.6 \mathrm{~km}^{2}$ (6\% of the grid cell area). Using NDVI only, the results were not significantly different than the model that includes Channel 3 (not shown). To establish the extent to which the model captured changes in land cover over time, we 


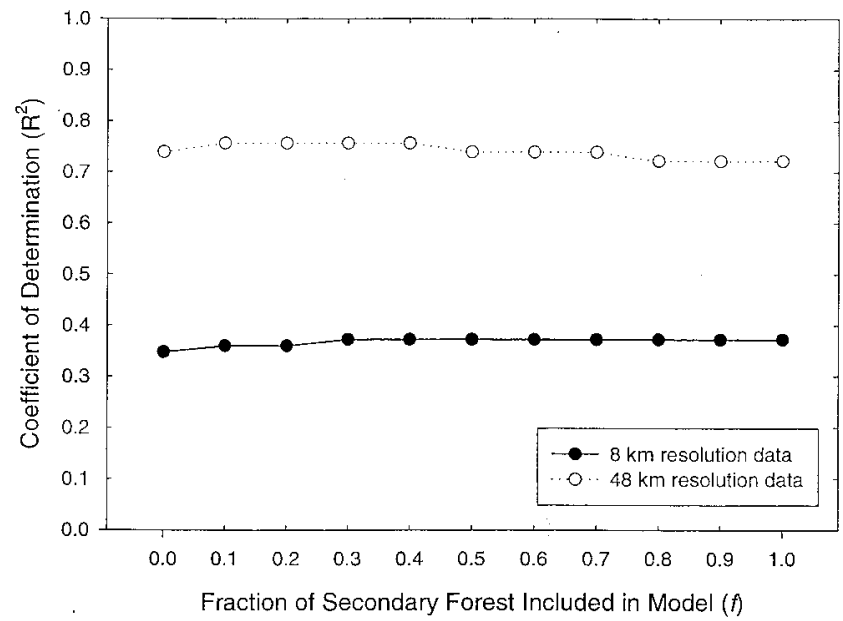

Figure 6. Coefficient of determination $\left(R^{2}\right)$ of the model (equation (1)) as a function of the free parameter $f$, or fraction of secondary forest included in the nonforest class (equation (2)), at $8-\mathrm{km}$ and $48-\mathrm{km}$ resolutions. Correlations had little sensitivity to secondary forest fraction.

grouped the cross-validation results by year and summed to the TM scene level. This process produced a single time series with an annual time step for the TM-observed values of nonforest and for the AVHRR cross-validated predictions derived from each resolution (Figure 8). We found the model derived, using 48-km aggregated AVHRR data, captures most of the interannual fluctuations in nonforested area $(R=0.91)$, while the 8 -km data are less successful $(R=0.73)$.

[25] To evaluate whether this model could recreate interannual dynamics of land cover at the pixel level, we compared the time series predictions of the cross-validation model to the observed nonforest fraction at each pixel. The results of this comparison were very poor at the 8-km resolution (not shown) and leave little hope of reconstructing a time series at this scale. At the $48-\mathrm{km}$ scale, however, the results were noticeably improved (Figure 9). The predicted time series for the pixels that did not change considerably over the 10 years of this analysis (the four pixels having a net change in the nonforested area from 1989 to 1998 of $<30 \mathrm{~km}^{2}$ ( $2 \%$ of the pixel)) show no relationship to the TM-observed time series. The six pixels that underwent a moderate change of between 30 and $350 \mathrm{~km}^{2}$ (1 to $15 \%$ of the pixel) have a moderate relationship between time series of predicted and observed nonforest fraction $(R=0.38$ to 0.66$)$. The five pixels that experienced the largest changes over the study period $\left(>350 \mathrm{~km}^{2}\right)$ have the strongest relationship ( $R=0.81$ to 0.97 ) between predicted and observed nonforest fraction. Therefore fine resolution data about changes in land cover at a decadal time step [Skole and Tucker, 1993] could be used to preselect pixels for an analysis of the type presented here. Pixels that change little in a 10 -year time period could be omitted from the analysis.

\section{Conclusions}

[26] Given the rapid and significant changes in tropical ecosystems associated with human disturbance, it is desirable to use existing remote sensing data to produce historical reconstructions of disturbed areas over time. The fine resolution Landsat data acquired since the 1970s represent a valuable store of information. This massive amount of data has been
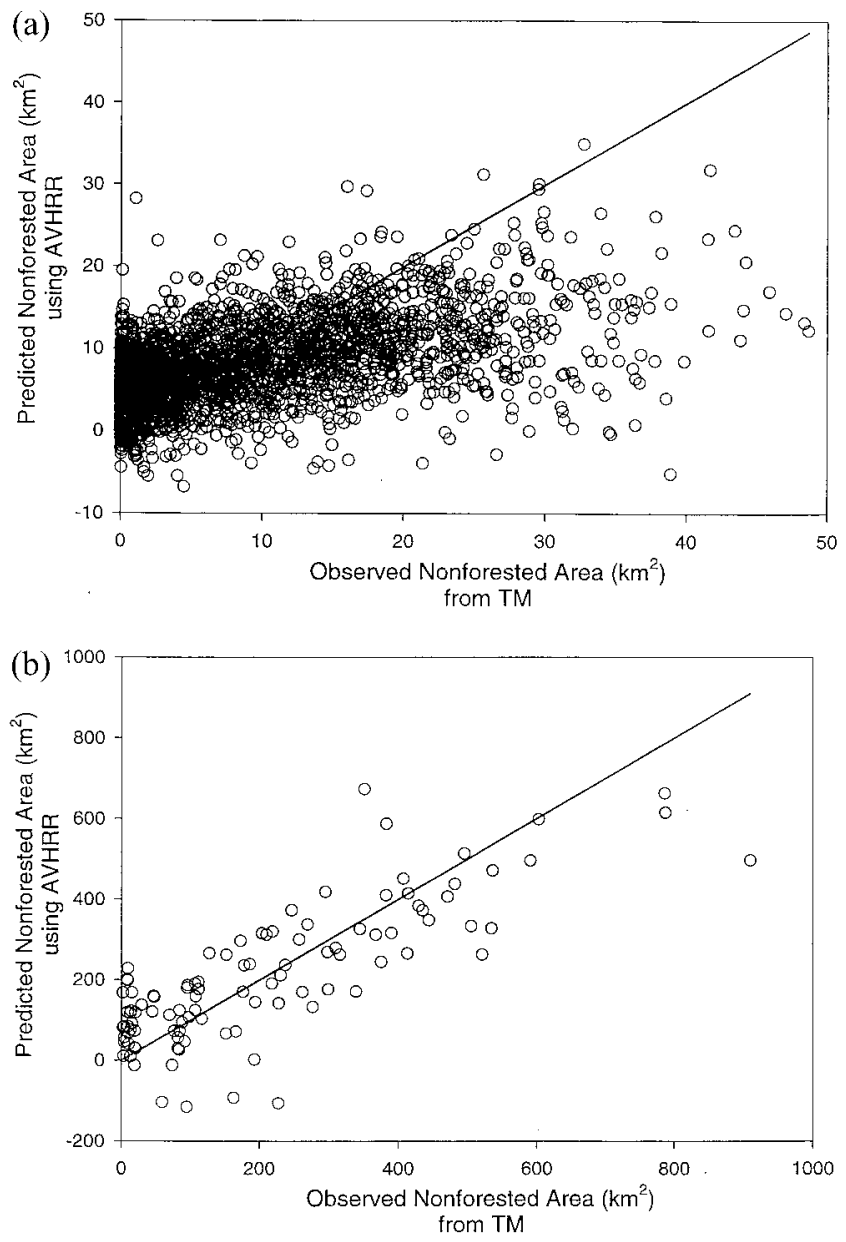

Figure 7. AVHRR-predicted versus TM-observed nonforested area based on cross-validation data at (a) $8-\mathrm{km}$ and (b) $48-\mathrm{km}$ resolution. Both figures include the one-to-one line.

effectively transformed into usable products [e.g., Chomentowski et al., 1994; Townshend et al., 1995] describing the state of ecosystems in the region. On their own, however, these fine resolution data are not adequate to ascertain the transitions of land cover at a timescale relevant for modeling global biogeochemistry, ecology or land-atmosphere interactions. Similarly, the global AVHRR data (1982 to present) are the only terrestrial observations available at spatial and temporal intervals that are regular and compatible with the scales of regional and global modeling. Technical complications and the coarse resolution of the observations, however, make interpretation difficult.

[27] Currently, terrestrial ecosystem models that consider distributions of land cover classes within relatively large grid cells [e.g., Moorcroft et al., 2001; Tian et al., 1998] are limited by a dearth of temporally and spatially rich land cover data. For this reason a historical land use product derived from a statistical combination of TM and AVHRR may be valuable to the modeling community. The unmixing method detailed here could be useful in interpolating annual estimates between the decadal estimates that are based solely on fine resolution data [e.g., Skole and Tucker, 1993]. This study demonstrates that annual estimates, based on this unmixing approach, are an improvement over a strictly linear interpolation between decadal products in this region of the tropics. 


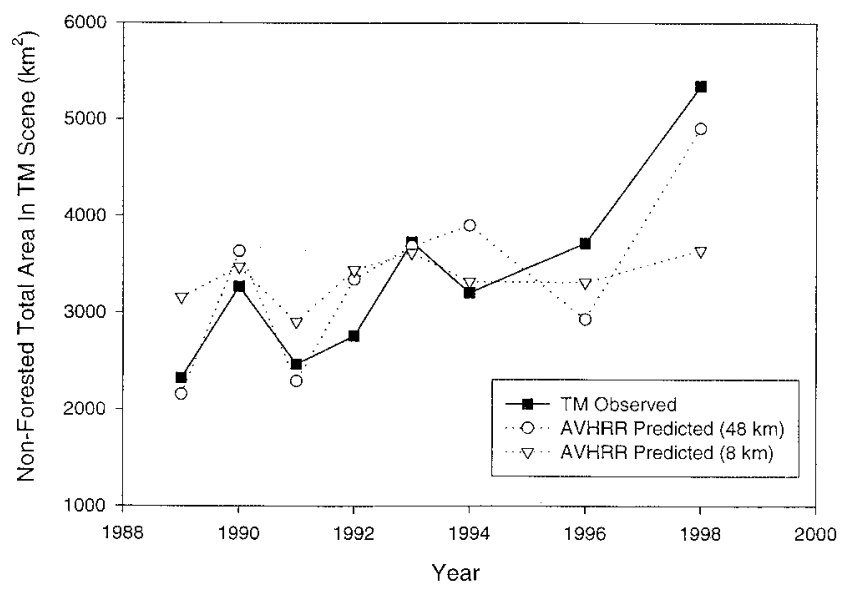

Figure 8. Time series of nonforested area summed over TM scene using the cross-validation data at the $8-\mathrm{km}$ and $48-\mathrm{km}$ resolution. The time series of AVHRR-predicted area in the 48- $\mathrm{km}$ resolution model (dotted line, circles) more accurately follows the TM-observed area (solid line, squares) than the AVHRR-predicted area in the $8-\mathrm{km}$ resolution model (dotted line, triangles).

[28] The analyses conducted in this paper demonstrate that reconstructions of changes in land cover distributions may be possible but with limited accuracy at the $8-\mathrm{km}$ spatial resolution of the AVHRR Pathfinder product. It is clear that the maximum-value compositing and standardization employed here were not sufficient to account for effects caused by water vapor, aerosols, GAC sampling, and georegistration complications. It is therefore probable that GAC-based AVHRR observations of the Amazon Basin are too noisy to extract reliable biophysical information about the land cover at the $8-\mathrm{km}$ resolution.

[29] The retrievals at $48 \mathrm{~km}$ were much more successful.

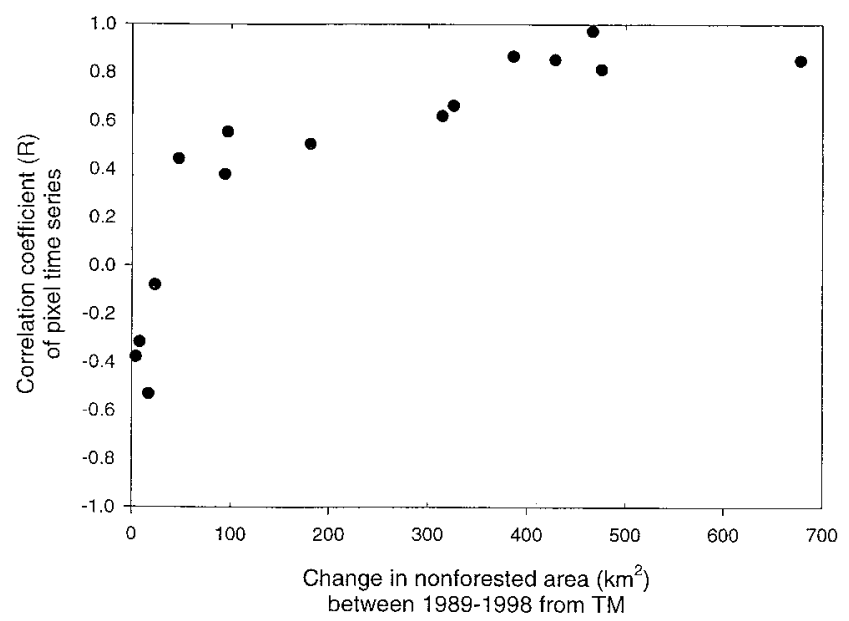

Figure 9. Temporal correlation $(R)$ versus change in nonforested area between 1989 and 1998 by pixel at the 48-km resolution. At the $8-\mathrm{km}$ resolution (not shown), there was no relationship between temporal correlation and change in nonforested area. At the $48-\mathrm{km}$ resolution the level of correlation between the predicted and the observed data at the pixel scale is related to the amount of land cover change over the 10 -year time series. Pixels that change significantly over the time period are accurately predicted by the AVHRR model.
These noted improvements probably result from two features of the aggregation process. First, aggregating the $8-\mathrm{km}$ data dilutes the effect of coregistration errors. Second, each aggregated $48-\mathrm{km}$ pixel has a larger sample size than the $8-\mathrm{km}$ PAL AVHRR GAC pixels. The 8 -km reflectances are averages of an irregular subsampling of the original LAC $1.1 \mathrm{~km}$ reflectances, not a measure of the reflectance from the entire $8-\mathrm{km}$ pixel. Aggregating up to $48 \mathrm{~km}$ increases the number of $1.1-\mathrm{km}$ LAC pixels that comprise the average and therefore produces reflectance values that are more representative of the actual land cover. Thus the power of a regression-based unmixing approach, such as the one presented in this paper, is most appropriately measured at spatial scales much larger than the single grid cell level ( $8 \mathrm{~km}$ in our case).

[30] Our results suggest that fine resolution remote sensing data can be combined successfully with moderate resolution data to provide accurate estimates of land cover distributions at a combined spatial and temporal resolution that is a compromise between the two types of data. This general approach is not necessarily limited to the use of parametric statistics or the assumption of linear relationships between reflectances (or indices) and land cover fractions [Braswell et al., 2000]. With new moderate remote sensing data designed to observe the terrestrial biosphere (e.g., MODIS), and fine resolution data (e.g., ASTER) designed to be used with their moderate resolution counterparts, we expect improvements in regressionbased unmixing approaches due to improved atmospheric correction calibration and improved knowledge of bidirectional reflectance distribution functions (BRDF), not to mention the finer spatial resolution of the global data sets.

\section{Notation}

$A_{\text {cleared }}$ area cleared (from TM land cover) for pasture/ cropland within a pixel.

$A_{\text {cerrado }}$ area in cerrado (from TM land cover) within a pixel.

$A_{\mathrm{nf}}$ area in nonforest (from TM, sum of other classes) within a pixel.

$A^{\prime}{ }_{\text {nf }}$ predicted area in nonforest within a pixel.

$A_{\text {sf }}$ area in secondary forest (from TM land cover) within a pixel.

$f$ fraction of area in secondary forest included in the nonforest class.

[31] Acknowledgments. This research was supported in part by grants from the NASA LBA-Ecology program and the NASA Interdisciplinary Science program. We thank the Skole/Pedlowski LBAEcology group (http://lba-ecology.gsfc.nasa.gov/Ibaeco/abstracts/skoleabstract.html) for the Landsat TM-based land cover product. The Pathfinder AVHRR Land (PAL) global 8-km AVHRR data were provided by NOAA/NASA. We also thank two anonymous reviewers for helping to improve the clarity and content of this manuscript. We are grateful to Ernst Linder for providing assistance with the statistical approach.

\section{References}

Allen, J. C., and D. F. Barnes, The causes of deforestation in developing countries, Ann. Assoc. Am. Geogr., 75, 163-184, 1985.

Alves, D. S., and D. L. Skole, Characterizing land cover dynamics using multi-temporal imagery, Int. J. Remote Sens., 17(4), 835-839, 1996.

Alves, D. S., J. L. G. Pereira, L. De Sousa, J. V. Soares, and F. Yamaguchi, Characterizing landscape changes in central Rondônia using Landsat TM imagery, Int. J. Remote Sens., 20(14), 2877-2882, 1999. 
Asner, G. P., Cloud cover in Landsat observations of the Brazilian Amazon, Int. J. Remote Sens., 22(18), 3855-3862, 2001.

Asner, G. P., C. A. Wessman, and J. L. Privette, Unmixing the directional reflectances of AVHRR sub-pixel landcovers, IEEE Trans. Geosci. Remote Sens., 35(4), 868-878, 1997.

Asner, G. P., A. R. Townsend, and B. H. Braswell. Satellite observations of El Nino effects on Amazon phenology and productivity, Geophys. Res. Lett., 27, 981-984, 2000.

Asrar G., M. Fuchs, E. T. Kanemasu, and J. H. Hatfield, Estimating absorbed photosynthetic radiation and leaf area index from spectral reflectance in wheat, Agron. J., 76, 300-306, 1984.

Atkinson, P. M., M. E. J. Cutler, and H. Lewis, Mapping sub-pixel proportional land cover with AVHRR imagery, Int. J. Remote Sens., 18(4), 917-935, 1997.

Batista, G. E., Y. E. Shimabukuro, and W. T. Lawrence, The long-term monitoring of vegetation cover in the Amazonian region of northern Brazil using NOAA-AVHRR data, Int. J. Remote Sens., 18, 3195 3210, 1997.

Braswell, B. H., E. Linder, S. Hagen, X. Xiao, S. Frolking, B. Moore, and J. Liu, A Bayesian unmixing algorithm for retrieving land cover distributions using global reflectance data, Eos Trans. AGU, 81(48), Fall Meet. Suppl., B11B-02, 2000.

Brown, S., and A. E. Lugo, Tropical secondary forests, J. Tropical Ecol., 6, 1- 32, 1990.

Chomentowski, W., W. A. Salas, and D. Skole, Landsat Pathfinder Project advances deforestation mapping, GIS World, 7, 34-38, 1994.

Di Maio Mantovani, A. C. and A. W. Setzer, Deforestation detection in the Amazon with an AVHRR-based system, Int. J. Remote Sens., 18(2), 273-286. 1997.

Fearnside, P. M., The rate and extent of deforestation in Brazilian Amazonia, Environ. Conserv., 17(3), 213-226, 1990.

Fearnside, P. M., Amazonian deforestation and global warming: Carbon stocks in vegetation replacing Brazil's Amazon forest, Forest Ecol. Manage., 80, 21- 34, 1996.

Foody, G. M., and D. P. Cox, Sub-pixel land cover composition estimation using a linear mixture model and fuzzy membership functions, Int. J. Remote Sens., 15(3), 619-631, 1994.

Foody, G. M., R. M. Lucas, P. J. Curran, and M. Honzak, Non-linear mixture modeling without end-members using an artificial neural network, Int. J. Remote Sens., 18(4), 938-953, 1997.

Frohn, R. C., K. C. McGwire, V. H. Dale, and J. E. Estes, Using satellite remote sensing to evaluate a socio-economic and ecological model of deforestation in Rondônia, Brazil, Int. J. Remote Sens., 17(16), 3233-3255, 1996.

Hecht, S. B., and A. Cockburn, The Fate of the Forest, Verso, London, 1989.

Hlavka, C. A., and M. A. Spanner, Unmixing AVHRR imagery to assess clearcuts and forest regrowth in Oregon, IEEE Trans. Geosci. Remote Sens., 33(3), 788-795, 1995.

Holben, B., Characteristics of maximum-value composite images from temporal AVHRR data, Int. J. Remote Sens., 7(11), 1417-1434, 1986.

Holben, B. N., and Y. E. Shimabukuro, Linear mixing applied to coarse spatial resolution data from multispectral satellite sensors, Int. J. Remote Sens., 14(11), 2231-2240, 1993.

Houghton, R. A., Tropical deforestation and atmospheric carbon dioxide, Clim. Change, 19, 99-118, 1991.

Houghton, R. A., D. S. Lefkowitz, and D. L. Skole, Changes in the landscape of Latin America between 1850 and 1985, Forest Ecol. Manage., 38, 143-199, 1991.

Houghton, R. A., D. L. Skole, C. A. Nobre, J. L. Hackler, K. T. Lawrence, and W. H. Chomentowski, Annual fluxes of carbon from deforestation and regrowth in the Brazilian Amazon, Nature, 403, 301-304, 2000.

Iverson, L. R., E. A. Cook, and R. L. Graham, A technique for extrapolating and validating forest cover across large regions: Calibrating AVHRR with TM data, Int. J. Remote Sens., 10(11), 18051812, 1989.

Iverson, L. R., E. A. Cook, and R. L. Graham, Regional forest cover estimation via remote sensing: The calibration center concept, Landscape Ecol., 9, 159-174, 1994.

James, M., and S. N. V. Kalluri, The Pathfinder AVHRR land data set: An improved coarse resolution data set for global monitoring, Int. J. Remote Sens., 15, 3347-3364, 1994.

Kerdiles, H., and M. O. Grondona, NOAA-AVHRR NDVI decomposition and subpixel classification using linear mixing in the Argentinean Pampa, Int. J. Remote Sens., 16(7), 1303-1325, 1995.
Kimes, D. S., R. F. Nelson, W. A. Salas, and D. L. Skole, Mapping secondary tropical forest and forest age from SPOT HRV data, Int. J. Remote Sens., 20(18), 3625-3640, 1999.

Li, Y., P. Mausel, Y. Wu, E. Moran, and E. Brondizio, Discriminating between advanced secondary succession and mature moist forest near Altamira, Brazil, using Landsat TM data, Proc. Am. Soc. Photogramm. Remote Sens., 350-364, 1994.

Lucas, R. M., M. Honzak, G. M. Foody, P. J. Curran, and C. Corves, Characterizing tropical secondary forests using multi-temporal Landsat sensor imagery, Int. J. Remote Sens., 14, 3061-3067, 1993.

Lucas, R. M., M. Honzak, P. J. Curran, G. M. Foody, R. Milne, T. Brown, and S. Amaral, Mapping the regional extent of tropical forest regeneration stages in the Brazilian Legal Amazon using NOAA AVHRR data, Int. J. Remote Sens., 21(15), 2855-2881, 2000.

Malingreau, J. P., F. Archard, C. Estreguil, H. J. Stibig, and G. D'Souza, NOAA-AVHRR based tropical forest mapping for southeast Asia, validated and calibrated with higher spatial resolution imagery, in Advances in the Use of NOAA AVHRR Data for Land Applications, edited by G. D'Souza, A. S. Belward, and J. P. Malingreau, pp. 279-309, Kluwer Acad., Norwell, Mass., 1996.

Mausel, P., Y. Wu, Y. Li, E. F. Moran, and E. S. Brondizio, Spectral identification of successional stages following deforestation in the Amazon, Geocarto Int., 4, 61-71, 1993.

Mayaux, P., and E. F. Lambin, Estimation of tropical forest area from coarse spatial resolution data: A two-step correction function for proportional errors due to spatial aggregation, Remote Sens. Environ., 53, 1-15, 1995.

Moorcroft, P. R., G. C. Hurtt, and S. W. Pacala, Scaling rules for vegetation dynamics: A new terrestrial biosphere model for global change studies, Ecol. Monogr., 71(4), 557-586, 2001.

Myneni, R. B., F. G. Hall, P. J. Sellers, and A. L. Marshak, The meaning of spectral vegetaqtion indices, IEEE Trans. Geosci. Remote Sens., 33, 481-486, 1995.

Nelson, R., Regression and ratio estimators to integrate AVHRR and MSS data, Remote Sens. Environ., 30, 201-216, 1989.

Nelson, R., and B. Holben, Identifying deforestation in Brazil using multiresolution satellite data, Int. J. Remote Sens., 7(3), 429-448, 1986.

Nelson, R. F., D. S. Kimes, W. A. Salas, and M. Routhier, Secondary forest age and tropical forest biomass estimation using TM, BioScience, 50(5), 419-431, 2000.

Nepstad, D. C., et al., Large-scale impoverishment of Amazonian forests by logging and fire, Nature, 398, 505-508, 1999.

Oleson, K. W., S. Sarlin, J. Garrison, S. Smith, J. L. Privette, and W. J. Emery, Unmixing multiple land-cover type reflectance from coarse spatial resolution satellite data, Remote Sens. Environ., 54, 98-112, 1995.

Pfaff, A. S. P, What drives deforestation in the Brazilian Amazon? Evidence from satellite and socioeconomic data, J. Environ. Econ. Manage., 37, 26-43, 1999.

Puyou-Lascassies, P., G. Flouzat, M. Gay, and C. Vignolles, Validation of the use of multiple liniear regression as a tool for unmixing coarse spatial resolution images, Remote Sens. Environ., 49, 155-166, 1994.

Ripple, W. J., Determining coniferous forest cover and forest fragmentation with NOAA-9 Advanced Very High Resolution Radiometer data, Photogramm. Eng. Remote Sens., 60(5), 533-540, 1994.

Salas, W. A., Optical and radar remote sensing of shifting cultivation in the tropics, Ph.D. thesis, Univ. of New Hampshire, Durham, N. H., 2001.

Schimel, D. S., Terrestrial ecosystems and the carbon cycle, Global Change Biol., 1, 77-91, 1995.

Skole, D., and C. Tucker, Tropical deforestation and habitat fragmentation in the Amazon: Satellite data from 1978 to 1988, Science, 260, 1905-1910, 1993.

Skole, D. L., W. H. Chomentowski, W. A. Salas, and A. D. Nobre, Physical and human dimensions of deforestation in Amazonia, BioScience, 44(5), 314-322, 1994.

Steininger, M. K., Satellite estimation of tropical secondary forest above-ground biomass: Data from Brazil and Bolivia, Int. J. Remote Sens., 21(6, 7), 1139-1157, 2000.

Stone, T. A., I. F. Brown, and G. M. Woodwell, Estimation, by remote sensing, of deforestation in central Rondônia, Brazil, Forest Ecol. Manage., 38, 291-304, 1991.

Tian, H., J. M. Melillo, D. W. Kicklighter, A. D. McGuire, J. V. K. Helfrich, B. Moore, and C. J. Vorosmarty, Effect of interannual 
climate variability on carbon storage in Amazonian ecosystems, $\mathrm{Na}$ ture, 396, 664-667, 1998.

Townshend, J. R. G., V. Bell, A. Desch, C. Havlicek, C. O. Justice, W. E. Lawrence, D. Skole, W. Chomentowski, and W. A. Salas, The NASA Landsat Pathfinder Humid Tropical Deforestation Project, in Land Satellite Information in the Next Decade, pp. IV76-IV87, Am. Soc. of Photogramm. and Remote Sens., Tysons Corner, Va., 1995.

Tucker, C. J., J. R. G. Townshend, and T. E. Goff, African land cover characterization using satellite data, Science, 227, 369-375, 1985.

Tucker, C. J. and J. R. G. Townshend, Strategies for monitoring tropical deforestation using satellite data, Int. J. Remote Sens., 21(6), 1461-1471, 2000.

Turner, B. L., W. B. Meyer, and D. L. Skole, Global land-use/land-cover change: Towards an integrated study, Ambio, 23(1), 91-95, 1994.

Uhl, C., R. Bushbacher, and E. A. S. Serro, Abandonded pasture in eastern Amazonia, I, Patterns of plant succession, J. Ecol., 76, 663681, 1988.

Woodwell, G. M., R. A. Houghton, T. A. Stone, R. F. Nelson, and W. Kovalick, Deforestation in the Tropics: New measurements in the Amazon Basin using Landsat and NOAA advanced very high resolution radiometer imagery, J. Geophys. Res., 92, 2157-2163, 1987.

Zhu, Z., and D. L. Evans, U.S. forest types and predicted percent forest cover from AVHRR data, Photogramm. Eng. Remote Sens., 60(5), 525-531, 1994.

B. H. Braswell, S. Frolking, S. C. Hagen, W. A. Salas, and X. Xiao, CSRC, Institute for the Study of Earth, Oceans, and Space, University of New Hampshire, Durham, NH 03824, USA. (rob.braswell@ unh.edu; steve.frolking@unh.edu; steve.hagen@unh.edu; wsalas@ agesmail.com; xiao@eos.sr.unh.edu) 


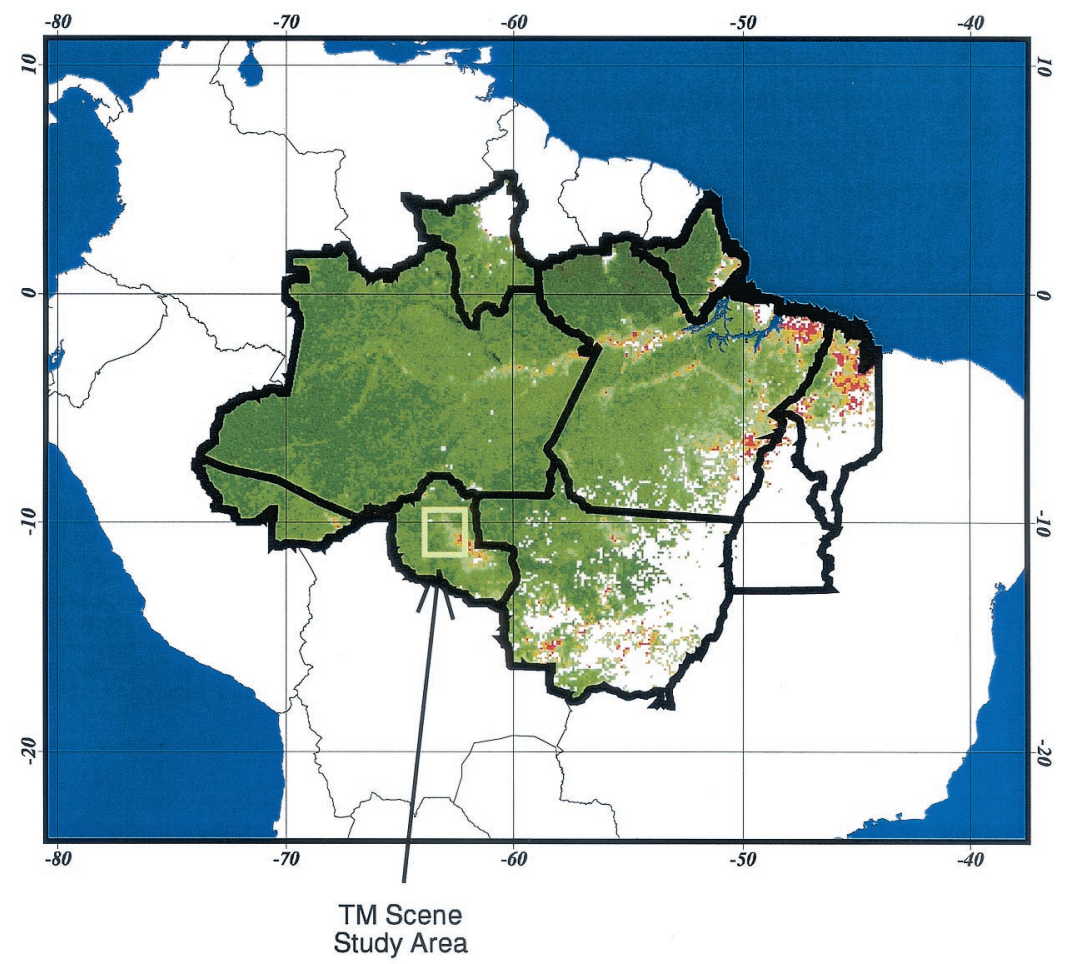

Figure 1. Region of study (rectangle) is located in Rondônia, Brazil, in the southwestern portion of the Legal Amazon (composed of the states in the dark outline). The color of 8-km pixels in the Legal Amazon represents the magnitude of the first principal component of Channels 1,2, and 3 in the 13-year-averaged AVHRR data. This view, which combines all the available AVHRR reflectance data for each pixel, reveals details of land cover such as the cleared area in Rondônia and along the Trans-Amazon Highway (orangepink-red coloring) and suggests usefulness of AVHRR time series data in identifying nonforested areas. 


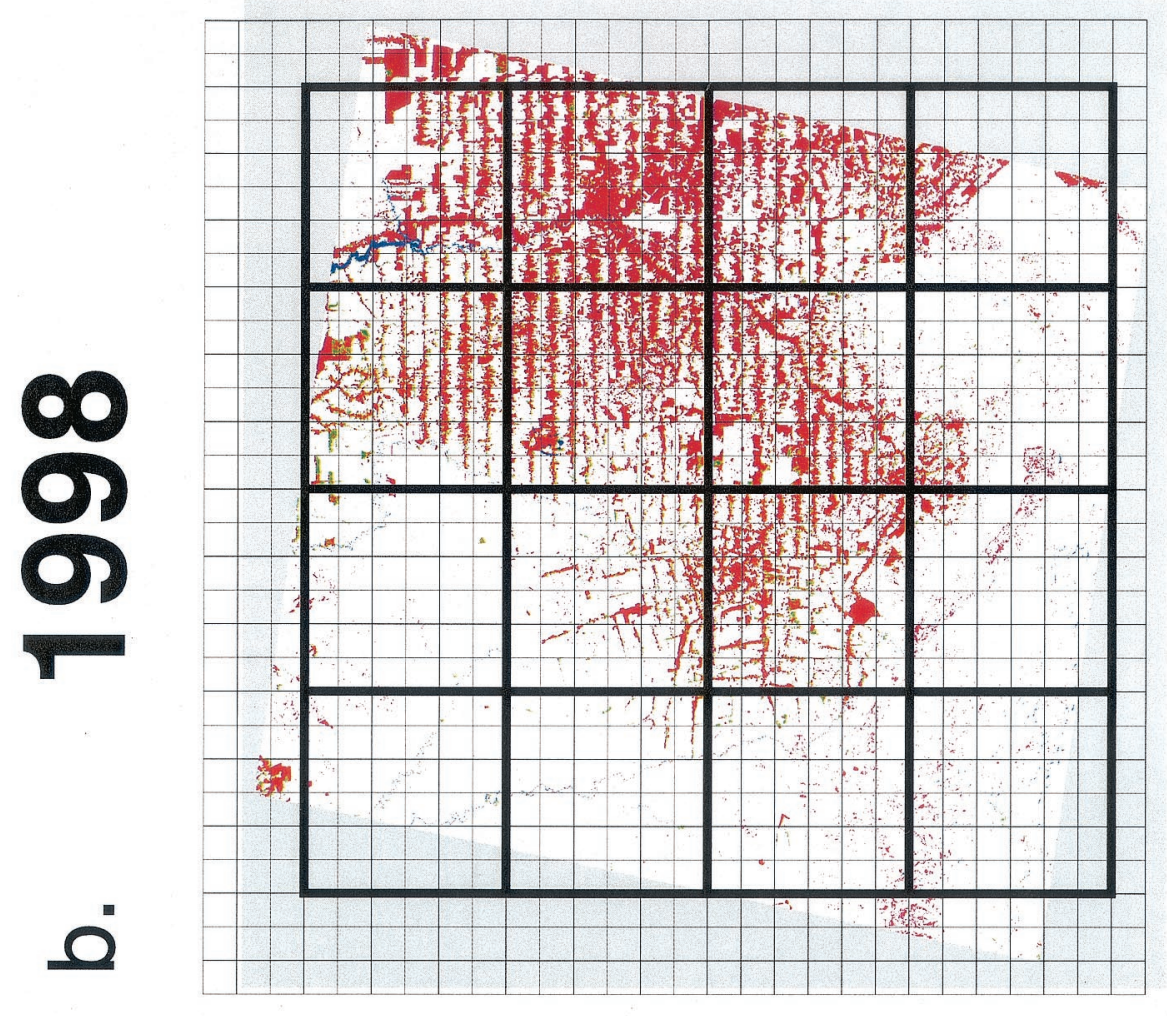

हี่

递严

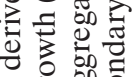

它施

बे

อิ듕ํㅇ

폻. 을

定春

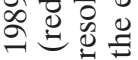

(త)

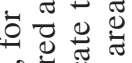

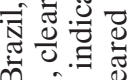

คิ.

跣. 要

总远范

है

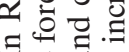

表完

늘응

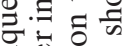

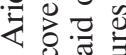

물

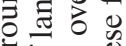

청 을

ฮั

ส

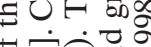

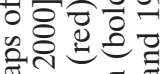

노요 프

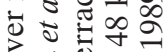

8 용

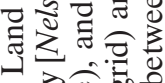

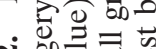

교율

㩆递它

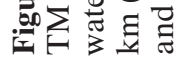



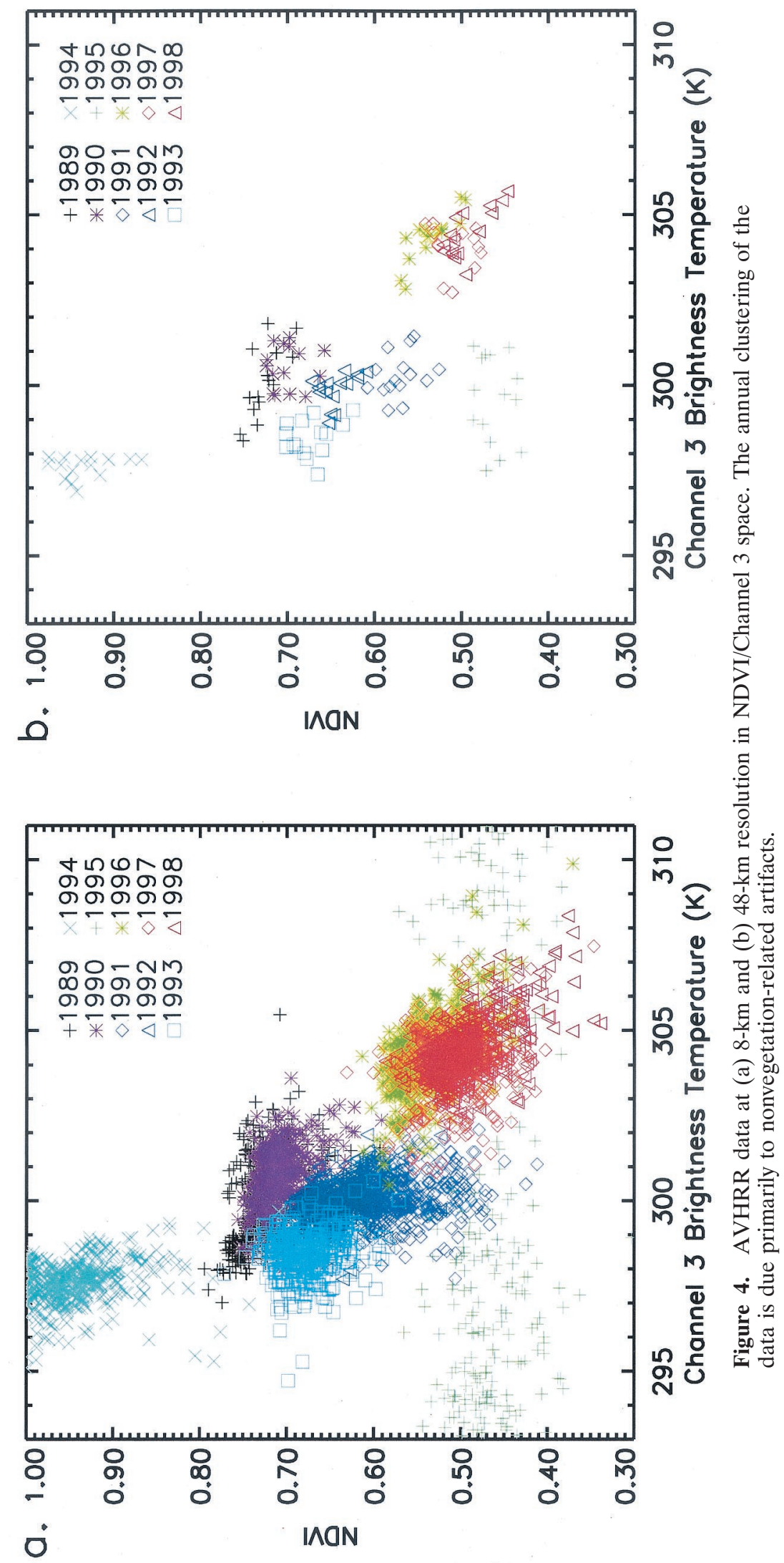